\title{
Equality and Inequality in Bosnia and Herzegovina
}

\author{
Soeren Keil
}

\section{1 \\ Introduction}

Bosnia and Herzegovina $(\mathrm{BiH})$ is a peculiar federal state. ${ }^{1}$ Some have referred to it as a confederal state; ${ }^{2}$ others call it a loose multinational federation. ${ }^{3}$ This author has described Bosnia as an imposed federal system, which is internationally administered by outside intervention in the political decision-making process. ${ }^{4}$ These different definitions and labels already demonstrate the complexity that is inherent in Bosnia's federalism and federation - namely the fact that it is hard to label and characterise the political system through the use of established terminology within the field of comparative federalism. ${ }^{5}$

This chapter discusses one aspect of this complexity: the issue of constitutional equality in Bosnia and Herzegovina. According to the 1995 Constitution, 'Bosniacs, Croats, and Serbs, as constituent peoples (along with Others), and citizens of Bosnia and Herzegovina' determine the Constitution. ${ }^{6}$ However, while the Constitution includes a focus on non-discrimination between different ethnic groups, it also introduces power-sharing mechanisms between Bosniaks, Serbs and Croats, to ensure their peaceful cooperation after the end of the war in 1995 and to address their desire to have a strong stake in the state. This includes, for example, the existence of a three-person Presidency, including one Bosniak and one Croat (elected in the mainly Bosniak-Croat Federation of Bosnia and Herzegovina) and one Serb member, elected in the Serb part of

1 The terms Bosnia, $\mathrm{BiH}$ and Bosnia and Herzegovina will be used interchangeably and always refer to the whole territory of the country known as Bosnia and Herzegovina.

2 Mirjana Kasapović, "Bosnia and Herzegovina: Consociational or Liberal Democracy?," Politička misao 42, no. 5 (2008): 3-30.

3 Florian Bieber, Post-War Bosnia, Ethnicity, Inequality and Public Sector Governance (Basingstoke, Hampshire: Palgrave Macmillan, 2006).

4 Soeren Keil, Multinational Federalism in Bosnia and Herzegovina (Farnham: Ashgate, 2013).

5 For a more general debate on this see Aleksandra Zdeb, "A Federation like No Other: The Case of Bosnia and Herzegovina," 50 Shades of Federalism (2018), https://5oshadesoffederalism. $\mathrm{com} /$ case-studies/federation-like-no-case-bosnia-herzegovina/.

6 Preamble of the Bosnia and Herzegovina Constitution of 1995. On this topic also Federal Equality in Multinational Bosnia and Herzegovina by Dejan Vanjek (chapter 13). 
Bosnia (Republika Srpska). Hence, equality is split between the equality of the three constituent peoples and the equality of the two entities in Bosnia.

Bosnia's Constitution also includes a long list of human rights provisions, which ensure the equal treatment of all people in Bosnia. As a result of this obvious contradiction between the rights of certain ethnic groups and all citizens of Bosnia, the European Court of Human Rights (ECHR) found in December 2009 that Bosnia discriminates against 'Others', because certain institutions in the state (i.e. the Presidency and the House of Peoples) only foresee representation for Bosniaks, Serbs and Croats. The judgement was the result of a complaint by a Bosnian Roma and a member of the Jewish community. However, to date it has not resulted in fundamental constitutional change. Yet, it is worth thinking about the very practical implications of this judgement, namely that a key element for ensuring peace in post-war Bosnia - ethnic power-sharing - might be modified and indeed questioned. This could also have potential consequences for the territorial division of Bosnia and the role of the constituent peoples and all other citizens of Bosnia and Herzegovina.

In order to demonstrate the complex - and contradictory - nature of equality (and inequality) in Bosnia's constitutional framework, I proceed as follows: in the first part, a discussion of the federal political system in Bosnia, its origins as a result of the war (1992-1995), and its development in the post-war era will be outlined, with the aim of demonstrating the multiple facets of equality (and inequality) within the different constitutional frameworks (at state, entity, cantonal and local level) in the country. In the second part, I discuss the origin of the Sejdić-Finci judgement of the European Court of Human Rights (ECHR) and outline the judgement and its meaning for Bosnia's constitutional reality. Finally, in the third part, I demonstrate why this judgement is so important for Bosnia, but also why the judgement has still not been implemented by Bosnian elites - more than ten years after the Court's original ruling.

\section{Federalism and Federation in Bosnia and Herzegovina - A Question of Equality?}

Bosnia's unique, and highly complex federal political system is the result of a three-and-a-half-year long conflict that devastated the country between 1992 and 1995. In the wake of the dissolution of Yugoslavia and after the independence declarations of Slovenia and Croatia, Bosniaks and Croats pushed for Bosnian independence as well. As a result of the independence declaration in April 1992, Serb elites, with the support of the Yugoslav army and paramilitary troops, began to establish zones of Serb autonomy, which were later united 
under the banner 'Republika Srpska' - the Serb Republic. The idea of the political project led by Radoslav Karadžić and military organised by Ratko Mladić ${ }^{7}$ was to create a coherent and united territory in Bosnia, in which all non-Serbs would be ethnically cleansed so that a homogenous Serbian territory could declare independence from Bosnia and later join Serbia or rump Yugoslavia. ${ }^{8}$ In addition to the conflict between Bosniaks and Croats on the one side, and Serbs on the other side, in 1993 a conflict broke out between the Bosniak army and Croat fighters, when Croat paramilitaries, with support from Croatia, fought for the secession of the Herzeg-Bosnia territory in the East of Bosnia, and its inclusion into Croatia. ${ }^{9}$ This conflict came to an end in early 1994 when, as a result of American pressure, the Presidents of Croatia and Bosnia signed the Washington Agreement. The Washington Agreement would create a military alliance between the two countries, and a Federation of several cantons in those territories of Bosnia which were under the control of the Bosniak and Croat militaries. Fighting eventually came to an end in Bosnia in late 1995 as a result of the Dayton Peace Agreement (DPA), which included a comprehensive peace plan for Bosnia and its future political organisation. Bosnia's current Constitution is included in the DPA as Annex IV. The DPA was the result of extensive US pressure on all parties in Bosnia, and would lay the foundations of the political developments in Bosnia that have played a key role until today. ${ }^{10}$

\subsection{The Dayton System}

The Bosnian state that the DPA created was one characterised by a number of contradictory principles. ${ }^{11}$ The federal system portrayed elements of both, an ethnic federation in the style of the Ethiopian federation, ${ }^{12}$ and a more

$7 \quad$ Both were later indicted and sentenced by the International Criminal Tribunal for the Former Yugoslavia (ICTY) for their role in ethnic cleansing campaigns, war crimes and genocide.

8 More generally on the dissolution of Yugoslavia see Laura Silber and Alan Little, The Death of Yugoslavia (London: Penguin Books and ввс Books, 1996). More specifically on Bosnia and Herzegovina see the excellent discussion in Steven Burg and Paul Shoup, The War in Bosnia-Herzegovina: Ethnic Conflict and International Intervention (Armonk, London: M.E. Sharpe, 1999).

9 Attila Hoare, "The Croatian Project to Partition Bosnia-Hercegovina, 1990-1994," East European Quarterly 31, no. 1 (March 1997): 121-138.

10 On the role of the USA in Bosnia see Richard Holbrooke, To End a War (New York: The Modern Library, 1999); Ivo Daalder, Getting to Dayton - The Making of America's Bosnia Policy (Washington D.C.: Brookings Institute, 200o).

11 Jens Woelk, "Bosnia and Herzegovina: Trying to Build a Federal State on Paradoxes," in Constitutional Dynamics in Federal States - Sub-national Perspectives, eds. Michael Burgess and Alan Tarr (Kingston, Montreal: McGill-Queen's University Press, 2012), 109.

12 On ethnic federalism in Ethiopia see David Turton, ed., Ethnic Federalism: The Ethiopian Experience in Comparative Perspective (Martlesham, Rochester: James Currey, 2006). 
classical European and North American federation, based on territorial, rather than ethnic principles. ${ }^{13}$ The federal system created was based on two territorial units, known as 'entities' - one of them, the Federation of Bosnia and Herzegovina (FBiH), was further sub-divided into ten cantons, while the other, the Republika Srpska (Rs), was highly centralised. In addition to these two entities, the Brčko District in the North East of the country was put under international administration and later through arbitration became an independent District, which belonged to both entities but was governed by neither neither (Figure 12.1, below). ${ }^{14}$

The $\mathrm{FBiH}$ was to control $51 \%$ of Bosnian territory, while the Rs controlled $49 \%$ of the territory, with the borders between the two very much reflecting the cease fire line established between the enemy armies in the late summer of 1995. However, since 1999, both entities had to give up territory when the Brčko District was formed as an independently administered unit within this complex federal system. ${ }^{15}$

All territorial units within the federation are based on ethnic criteria, with the exception of Brčko District and the two mixed cantons in the FBiH, in which mainly Bosniak and Croats live. A census in 2013 confirmed the homogenous nature of the different territories in Bosnia, with 92.11 \% of all Serbs in Bosnia living in the Rs, as well as $88.23 \%$ of all Bosniaks and $91.39 \%$ of all Croats in Bosnia living in the $\mathrm{FBiH} .{ }^{16}$ The ten cantons within the $\mathrm{FBiH}$ themselves are more or less ethnically homogenous, with five of them having a clear Bosniak majority, three having a clear Croat majority, and only the Central Bosnia and the Herzegovina Neretva cantons having a mixed population, mainly consisting of Bosniaks and Croats.

Yet, while the territorial organisation of the country might indicate the installation of a federal system based on exclusive ethnic criteria, this is not

13 On territorial federalism, and particularly the European tradition of federalism see Michael Burgess, Comparative Federalism: Theory and Practice (Basingstoke, New York: Routledge, 2006), 162-191.

14 A Map of Bosnia's complex federal system, published by the Office of the High Representative in Bosnia and Herzegovina on 7 October 2003, can be found at http:// reliefweb.int/map/bosnia-and-herzegovina/federation-bosnia-and-herzegovina.

15 For the final decision of the Arbitration Tribunal see Office of the High Representative, Arbitral Tribunal for Dispute over Inter-Entity Boundary in Brcko Area, Final Award, 5 March 1999, http://www.ohr.int/?ohr_archive=arbitral-tribunal-for-dispute-over-interentity-boundary-in-brcko-area-final-award.

16 Rodolfo Toe, "Census Reveals Bosnia's Changed Demography," BalkanInsight, 30 June 2016, http://www.balkaninsight.com/en/article/new-demographic-picture-of-bosnia -finally-revealed-o6-3o-2016. 


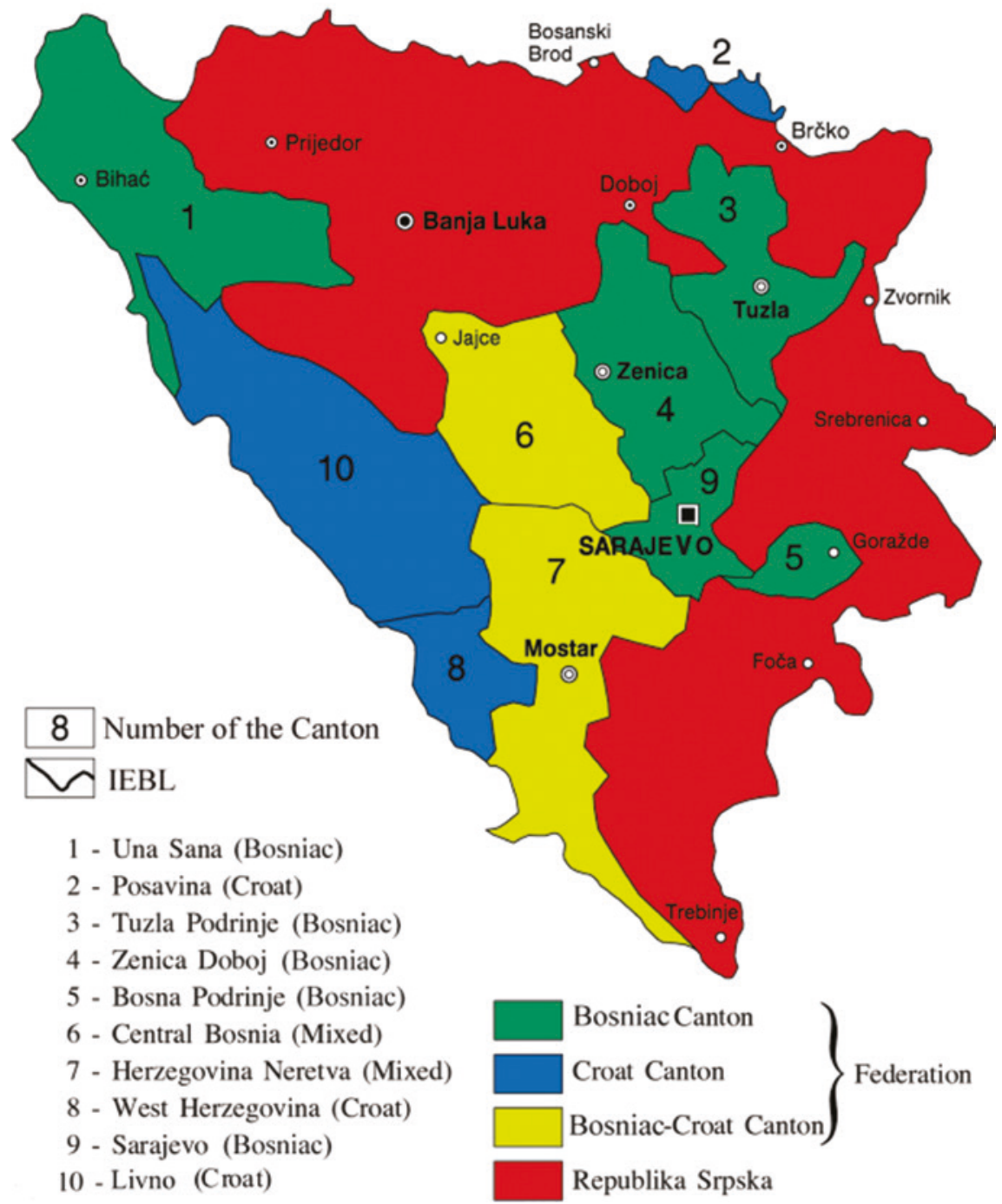

FIGURE 12.1 Map of Bosnia's complex federal system

The name of canton ten has been declared illegal by the Constitutional Court of the FBiH, because 'Herceg Bosna' refers to the Croat statelet that tried to secede from Bosnia during the war. The canton has since been referred to as Canton 10.

SOURCE: OFFICE OF THE HIGH REPRESENTATIVE IN BOSNIA AND HERZEGOVINA (SEE FOOTNOTE 14) 
completely the case. ${ }^{17}$ An important ruling by the Bosnian Constitutional Court in 2000 established that the two entities cannot claim to represent one (or two) of the constituent peoples exclusively, as was the case until then. The RS claimed in fact to represent 'the Serbs in Bosnia and Herzegovina', while the Constitution of the FBiH referred only to Bosniaks and Croats as constituent peoples until then. The Constitutional Court found this practice to be a breach of the Bosnian Constitution, which outlines Bosniaks, Serbs and Croats (along with Others) as constituent peoples, hence - so the Court ruled - they also have to be constituent peoples in all territories of the country. ${ }^{18}$ This creates a legal situation in which Bosniaks, Serbs and Croats are recognised as constituent peoples in the whole country, and in each of the entities and in the Brčko District, while in terms of demography it can clearly be argued that certain territorial units represent only one (or two) of these groups. This has very complicated and indeed negative consequences for the institutional representation of these three groups in the different territories of Bosnia, as will be discussed below.

In addition to this complex federal system, the DPA also established a federal political system that was highly decentralised. Indeed, in 1995 the Constitution only assigned the following responsibilities to the institutions of $\mathrm{BiH}$ : foreign policy, foreign trade policy, customs policy, monetary policy, finances of the institutions; regarding the country's international obligations, it assigned federal government immigration, refugee and asylum policy, international and inter-Entity criminal law enforcement, establishment and operation of common international communication facilities, regulation of inter-Entity transportation and air traffic control. ${ }^{19}$ All other competences, including military and defence, policing, taxation and tax collection, economic and social welfare policies, amongst others, were given to the entities. Article III.za of the Bosnian Constitution states specifically: 'All governmental functions and powers not expressly assigned in this Constitution to the institutions of Bosnia and Herzegovina shall be those of the Entities. ${ }^{20}$ Bosnia, in other words, became one of the most decentralised federal systems in the world. This situation has not changed fundamentally to this day, despite some processes of

17 Soeren Keil, "Mythos und Realität eines ethnischen Föderalismus in Bosnien und Herzegowina," Südosteuropa Mitteilungen 5o, no. 1 (2010): 76-86.

18 Constitutional Court of Bosnia and Herzegovina, Judgement no. U-5/98, 'On Constituency', para 55, 6o, available at http://www.ccbh.ba/odluke/). The judgement is however more widely known as 'Constituent Peoples Case '.

19 Bosnian Constitution, Art. III.1 a-j.

20 Bosnian Constitution, Art.III.3a. 
centralisation taking place ${ }^{21}$ over the last twenty years, in particular through the creation of a centralised Defence Ministry, through the Indirect-Taxation Authority, and the centralisation of border security provisions. ${ }^{22}$

In addition to the high degree of decentralisation, it needs to be pointed out that Bosnia is a nearly perfect example of Arend Lijphart's consociational democracy model. ${ }^{23}$ Strict power-sharing applies to all of Bosnia's central institutions. In the Executive, the semi-presidential system is characterised by a rotating presidency consisting of three members: one Bosniak and one Croat who are elected in the FBiH, and one Serb who is elected in the Rs. The government therefore consists of two-thirds of Ministers from the $\mathrm{FBiH}$ and one-third of Ministers from the RS and is called Council of Ministers. ${ }^{24}$ In the legislative branch, there are two chambers of parliament. The House of Representatives, which is elected through proportional representation, consists of two-thirds of MP s from the FBiH and one-third of MP s from the Rs. The second chamber, the House of Peoples, consists of fifteen members: five Bosniaks and five Croats elected from the FBiH parliament, and five Serbs elected from the RS assembly. ${ }^{25}$ In the judiciary branch, the Constitutional Court consists of nine judges: four are appointed from the $\mathrm{FBiH}$ and two are appointed by the Rs, while three judges are appointed by the President of the European Court of Human Rights. These last three are international judges who cannot be citizens of Bosnia or any of its neighbouring countries. ${ }^{26}$ Decisions require a majority in both houses, and due to complex veto regulations, Bosniak, Serb and Croat parties have to work together in order to establish the required

21 It is worth mentioning that all these centralisation efforts were driven by external actors rather than Bosnian elites. This is why I referred to Bosnia as an internationally administered federation earlier.

22 For an assessment of the developments within Bosnia's political system see Soeren Keil and Valery Perry, "Introduction: State-Building and Democratization in Bosnia and Herzegovina," in State-Building and Democratization in Bosnia and Herzegovina, eds. Soeren Keil and Valery Perry (London, New York: Routledge, 2015), 1-14; as well as Soeren Keil and Anastasiia Kudlenko, "Bosnia and Herzegovina 20 Years after Dayton: Complexity Born of Paradoxes," International Peacekeeping 22, no. 5 (2015): 471-489.

For a more recent discussion of some of the disfunctionalities of the system and how they feed into public unrest see Jasmin Mujanović, Hunger and Fury - The Crisis of Democracy in the Balkans (London: Hurst and Co., 2018).

23 On Lijphart's model see Arend Lijphart, Democracy in Plural Societies (New Haven: Yale University Press, 1977).

24 Bosnian Constitution, Art. v: Presidency.

25 Bosnian Constitution, Art. IV: Parliamentary Assembly.

26 Bosnian Constitution, Art. vi: Constitutional Court. 
majorities and prevent any vetoes. ${ }^{27}$ This complex power-sharing architecture is also applied to the entities, cantons and even in municipalities. However, as mentioned above, most of these units are ethnically homogenous, and since ethnic identity is based on self-identification, it is easy for the ruling parties in certain territories to have self-declared Bosniaks, Croats, Serbs and Others on their party list and fill the seats reserved for these groups by loyal party members. There is no institutional provision for example to prevent a Serb in the RS supporting the dominant Serb party to declare themselves as a Croat and take one seat reserved for Croats in the government of the Rs. While this does not happen at central level, it is a very common practice in the cantons of the $\mathrm{FBiH}$, and also at municipality level, where seats are either filled by loyalists to the dominant group (through self-declaration), or seats reserved for other groups remain empty, because there are no representatives of these other groups in these municipalities.

\subsection{The Equality Question}

The Dayton system introduced a political framework, which attempts on the one hand to find a balance between equality and power-sharing between Bosniaks, Serbs and Croats, and on the other hand, the protection of individual liberal (non-ethnically focused) rights. For example, while the discussion above has demonstrated the complex power-sharing nature of Bosnia's political system, the Constitution, in Article II, provides a long list of Human Rights and Fundamental Freedoms. It goes as far as stating in Article II.2 that ' $[\mathrm{t}] \mathrm{he}$ rights and freedoms set forth in the European Convention for the Protection of Human Rights and Fundamental Freedoms and its Protocols shall apply directly in Bosnia and Herzegovina. These shall have priority over all other law.' In light of Article II and its link to Bosnia's human rights and fundamental freedoms' regime, it could be argued that Bosnia probably has one of the most advanced human rights regimes, and one of the most extensive protections for human rights and fundamental freedoms, not least because the provisions in Bosnia's Constitution are linked to the European Convention for the Protection of Human Rights and Fundamental Freedoms (ECtHR) of the Council of Europe, which in case of conflict, has priority. This embedded rights protection is connected with a clear commitment to non-discrimination, as stated in Article II.4 of the Bosnian Constitution:

27 On the complex veto system in Bosnia see Birgit Bahtić-Kunrath, "Of Veto Players and Entity Voting: Institutional Gridlock in the Bosnian Reform Process," Nationalities Papers 39, no. 6 (2011): 899-923, https://doi.org/10.108o/oo905992.2011.614224. 
The enjoyment of the rights and freedoms provided for in this Article or in the international agreements listed in Annex I to this Constitution shall be secured to all persons in Bosnia and Herzegovina without discrimination on any ground such as sex, race, color, language, religion, political or other opinion, national or social origin, association with a national minority, property, birth or other status.

On paper, therefore, $\mathrm{BiH}$ seems to be one of the most advanced countries when it comes to the protection of human rights and fundamental freedoms. Yet, when looking at international monitoring organisations such as Freedom House, Bosnia scores as partially free overall, with a 4 out of 7 score for freedom rating, 4 out of 7 for political rights and 4 out of 7 for civil liberties. ${ }^{28}$ Likewise, the Bertelsmann Transformation Index in its 2018 report for $\mathrm{BiH}$ places the country in the category of a 'defective democracy'. ${ }^{29}$ This contrast between extensive protection of human rights and fundamental freedoms on the one side, and poor performance in the indexes of international think tanks on the other side is rather puzzling.

One explanation can be found in the above-mentioned contrast between ethnically based power-sharing and the provisions for human rights and fundamental freedoms. These seem to be in direct and obvious conflict. For example, one could wonder how the rights of Bosniaks and Croats in the Rs can be protected, when the RS understands itself - and indeed until 2002 referred to itself in its Constitution - as the entity of Serbs in Bosnia. The FBiH did the same, by only mentioning Bosniaks and Croats (amongst Others). Hence, until the above-mentioned judgement of the Constitutional Court in 2000, the equality of Bosniaks, Serbs and Croats (and of Others) was not ensured throughout the territory of Bosnia, and the Constitutions of the entities allowed the positive discrimination of the majority ethnic group(s). This exclusion mechanism can also be found in a less formalised and less radical way in other federal states, such as Canada, where Quebec can discriminate against immigrants based on its own language laws, and in Belgium and Switzerland, where the territoriality principles also favour one language group over others in a certain territory. In $\mathrm{BiH}$, this form of exclusion was found illegal by the Constitutional Court in

28 In Freedom House's scale, 1 means most free, 7 means least free. Bosnia's 2018 report and scores are available at Freedom House, "Freedom in the World 2018, Bosnia and Herzegovina," https://freedomhouse.org/report/freedom-world/2018/bosnia-and -herzegovina.

29 "Bertelsmann Transformation Index, Bosnia and Herzegovina 2018," https://atlas.btiproject.org/share.php? ${ }^{*}{ }^{*} 2018^{*} \mathrm{CV}: \mathrm{CTC}: S E L B I H^{*} \mathrm{CAT}{ }^{*} \mathrm{BIH}^{*} \mathrm{REG}: \mathrm{TAB}$. 
reference to its Constitution, which clearly states that the three ethnic groups (Bosniaks, Serbs and Croats) have to be treated equally across the whole territory of Bosnia and Herzegovina. It took until 2002, and extreme pressure by international actors, before the entities were to change and amend their Constitutions in order to comply with the judgement of the Court. ${ }^{30}$ However, while this judgement dealt with the question of equality between the three constituent peoples across the territory of Bosnia and Herzegovina, it did not engage with the strange constitutional status of 'The Others' - which are mentioned in brackets in the Constitution, but which are excluded from many of the power-sharing arrangements in the country. This question would only be dealt with nine years later in the famous Sejdić-Finci judgement of the ECHR.

\section{3}

Equality and the Sejdić-Finci Judgement of the ECH R

The 2009 judgement of the ECHR in the case of Sejdić-Finci vs. Bosnia and Herzegovina ${ }^{31}$ was the result of a complaint by Dervo Sejdić, a leading Roma activist and Jakob Finci, a public intellectual and prominent member of the Bosnian Jewish community. They originally complained about their inability to stand for election to both the House of Peoples and the Presidency of Bosnia and Herzegovina, based on their Roma and Jewish origin, referring to Articles 3, 13 and 14 of the ECtHR, as well as Article 3 of Protocol No. 1 and Article 1 of Protocol No. 12 - in short claiming that this constituted a form of discrimination based on racial/ethnic self-identification, which is not in line with the ECtHR. The Bosnian Constitutional Court immediately referred the case to the ECHR, because the claim was based on the ECtHR, which has priority over all Bosnian laws, as discussed above. The Court indeed ruled that a violation of Article 14 of the ECtHR in conjunction with Article 3 of Protocol No. 1 in relation to the House of Peoples could be found, as well as a violation of Article 1 of Protocol No. 12 in relation to the Presidency. The Court therefore established

30 For a wider discussion on the Constituent Peoples Case see International Crisis Group, "Implementing Equality: The 'Constituent Peoples' Decision in Bosnia and Herzegovina," ICG Balkans Report, no. 128 (Sarajevo, Brussels: 2002); Peter Neussl, "The Constituent Peoples Decision of the Constitutional Court and the Sarajevo-Mrakovica Agreement A 'Milestone Product' of the Dayton Concept?," in Dayton and Beyond: Perspectives on the Future of Bosnia and Herzegovina, eds. Christophe Solioz and Tobias Vogel (BadenBaden: Nomos, 2004), 65-73.

31 European Court of Human Rights, Grand Chamber, Sejdić and Finci v. Bosnia and Herzegovina (application nos. 27996/o6 and 34836/o6), judgment of 22 December 20o9, hereafter Sejdić-Finci case. 
that Bosnia discriminated against both complainants on the basis of their ethnicity without 'objective and reasonable justification.' ${ }^{32}$ What is more, the Court established that the relevant constitutional provisions in Bosnia in relation to the Presidency and the House of Peoples, as well as the accompanying electoral laws would have to change in order to address and eliminate this form of discrimination. It is worth highlighting that the judgement of the ECHR was not unanimous, and that discrimination in the election of the House of Peoples was agreed by 14 judges (against 3) and for the Presidency of Bosnia by 16 judges (against 1). In their opinions, the dissenting judges highlighted the need to take more strongly into account the historical evolution of Bosnia's complex power-sharing system, which was first and foremost an instrument of peace-building after the war in the country. Within academia, the judgement has also been criticised by those supporting power-sharing regimes in postconflict societies, who have argued that the judgement is a threat to enforced cooperation and consensus that is often key in post-conflict countries, and it threatens to undermine the legitimacy of international courts, when these intervene in the internal affairs of states to such a drastic extent. ${ }^{33}$ Many academics, however, argued that the judgement could be a chance for Bosnia to promote human rights over selected group rights and break open some of the strict power-sharing rules in order to make the system more flexible and enhance its democratic credentials. ${ }^{34}$

Despite the original window of opportunity that was opened as a result of the ECHR's judgement in the Sejdić-Finci case, implementation has since been lacking. There has been no major revision of the Bosnian Constitution since 1995, and BiH has been pushed by the Council of Europe, the European Union $(\mathrm{EU})$ and other international agencies to implement the judgement urgently. However, the failure to implement this court judgement highlights another key feature of Bosnia's complex political system - although nobody is really happy with the Dayton provisions, there is a complete lack of agreement on what should be changed and the direction these changes should take. Bosniak, Serb

32 Sejdić-Finci case, p. 32.

33 See here particularly Christopher McCrudden and Brendan O'Leary, Courts and Consociations (Oxford, New York: Oxford University Press, 2013).

34 Amongst many see Elyse Wakelin, "The Sejdic and Finci Case: More Than Just a Human Rights Issue?," E-International Relations (October 2012), http://www.e-ir.info/2012/10/31/ the-sejdic-and-finci-case-more-than-just-a-human-rights-issue-for-bosnia-and-herzegovina/; Lindsey Wakely, "From Constituent Peoples to Constituents: Europe Solidifies Fundamental Political Rights for Minority Groups in Sejdic v. Bosnia," North Carolina Journal of International Law and Commercial Regulation 36, no. 1 (Autumn 2010): 233-254. 
and Croat elites have very different visions of the Bosnian state, and they all have their own interests to protect; therefore, they favour the current status quo over any change that might harm their current position in the system. ${ }^{35}$ Likewise, the many suggestions about reform possibilities that emerged from political parties and civil society organisations after 2009 have so far failed to gain wider recognition, as well as the local and international support needed for a push for wider reform of this complex institutional architecture. ${ }^{36}$ What all these different proposals have in common is a contested notion of equality any form of judgement implementation has in recent years become a battleground for all ethnic groups in the country to claim that they are discriminated against and disadvantaged by the Dayton provisions. Bosniak elites feel that as the representatives of the majority population they are constrained in a system in which the rights of smaller communities (such as the Serbs and Croats) are disproportionally protected and undermine the 'one person, one vote' principle. Likewise, Serb elites feel that the rights of the Rs, and of Serbs in Bosnia generally, need to be protected and enhanced, and that processes of centralisation since 1995 have undermined the originally guaranteed autonomy of Serbs in the Bosnian state. Finally, Croat elites, representing the smallest of the three constituent peoples, argue that the current institutional provisions disadvantage them, because they see themselves as a junior partner to Bosniaks in the $\mathrm{FBiH}$, and instead demand the creation of a third - Croat - entity to ensure that each ethnic group would have their own territory with guaranteed autonomy provisions. ${ }^{37}$ The political debate on the Sejdić-Finci judgement has therefore shifted since 2009, as it is no longer about implementing a judgement which at its heart complained about ethnic discrimination of 'the Others' in Bosnia's complex system at the expense of power-sharing between elites representing the former warring groups of Bosniaks, Serbs and Croats; instead, the debate

35 Kurt Bassuener, "The Dayton Legacy and the Future of Bosnia and the Western Balkans House Foreign Affairs Committee Hearing," Written Statement for the Congressional Record (April 2018), http://www.democratizationpolicy.org/pdf/Bassuener_US_Congressional_ Hearing_Written_Statement_4_18.pdf.

36 Valery Perry, "Constitutional Reform Processes in Bosnia and Herzegovina: Top-Down Failure, Bottom-Up Potential, Continued Stalemate," in State-Building and Democratization in Bosnia and Herzegovina, eds. Soeren Keil and Valery Perry (London, New York: Routledge, 2015), 15-40.

37 For a wider discussion on these constitutional debates and their legal quagmire see Valery Perry, "Constitutional Reform in Bosnia and Herzegovina: Does the Road to Confederation go through the EU?," International Peacekeeping 22, no. 5 (2015): 490-510; Soeren Keil and Valery Perry, "Introduction: Bosnia and Herzegovina 20 Years after Dayton," International Peacekeeping 22, no. 5 (2015): 463-470. 
is now about the extent to which the Dayton system should be reformed so these three groups, and especially the elites that represent them, can have a stronger stake in the country, and how equality amongst them can and should be implemented through means of both institutional and territorial (meaning creation of new federal units) engineering. This has, once again, resulted in a complete ignorance of the main aim of the judgement, namely, to make the system less ethnically exclusive and to allow all Bosnian citizens to access its core institutions.

Learning from Bosnia? Wider Theoretical and Empirical Implications of the Sejdić-Finci Judgement and Its Aftermath

The discussion surrounding the state-building and federalisation experience in $\mathrm{BiH}$, now over twenty years after the war ended and with the installation of the federal system, questions federalism and its understanding, as well as power-sharing, equality, and the processes of peace- and state-building. After the extensive discussion on Bosnia's institutional framework above, and the arguments surrounding the Sejdić-Finci case and its impact on equality, it is necessary at this stage to return to the overall theme of this book - namely the question of equality in federal states. In order to do this, a number of areas need to be considered in further detail, and the theoretical and empirical implications of the Bosnian case for these areas need to be teased out.

\subsection{Power-Sharing as Peace-Building and the Question of Equality}

As demonstrated above, the power-sharing arrangements within Bosnia's political system are extremely complicated. Yet, the provisions for the Presidency, which exclusively allow Bosniaks and Croats from the FBiH, and Serbs from the Rs, to stand in elections, and the provisions for the appointment of the House of Peoples (five Bosniaks, five Croats appointed by the FBiH parliament, and five Serbs appointed by the Rs Assembly) had in particular been heavily criticised, even before the Sejdić-Finci judgement. ${ }^{38}$ The ECHR judgement in the Sejdić-Finci case confirmed previous concerns about unjustified ethnic discrimination. Yet, critics and indeed the dissenting judges at the ECHR have pointed out that the power-sharing provisions in Bosnia, while nominally

$38 \quad$ For one of these critiques see European Commission for Democracy through Law (Venice Commission), Opinion on the Constitutional Situation of Bosnia and Herzegovina and the Powers of the High Representative (CDL-AD (2005)O04), 11 March 2005, https://www.venice.coe.int/webforms/documents/default.aspx?pdffile=CDL-AD(2005)oo4-e. 
discriminating, serve a greater good, namely the protection of peace in a postwar society. ${ }^{39}$ The paradox that emerges from this debate can be found in the following question: is it justified that in post-war countries institutional mechanisms might exclude some communities from certain institutions, when these arrangements serve the purpose of uniting and bringing together former enemies and therefore contribute to peace-building? In other words, is it acceptable to build in discriminatory mechanisms into specific institutions if these mechanisms serve the greater good of keeping the peace? Answers to this question vary, with some authors vehemently arguing for discriminatory practices within power-sharing arrangements, claiming that these mechanisms ultimately serve to protect peace. These authors have also highlighted that in the case of Bosnia, both Sejdić and Finci could have run for the Presidency, had they chosen to self-identify as Bosniaks or Croats (both were living in the $\mathrm{FBiH}$ at the time). Hence, it was their choice to identify as Roma and as a member of the Jewish community, which they knew would lead to their exclusion from the elections for the Presidency. ${ }^{40}$

The counter-argument is that democracy in post-war societies cannot be built if certain groups, irrespective of their size and political importance within the country, are systematically (and also constitutionally, which is especially the case in $\mathrm{BiH}$ ) excluded from political participation in key state institutions. This, so the argument goes, only lays the foundation for future conflicts, and undermines any aspirations to build an inclusive liberal democracy. ${ }^{41}$ While critiques to this approach would argue that politics in post-conflict countries is not about liberal democracy but about preserving peace by ensuring inclusion of the major groups in decision-making and therefore promoting the idea of consociational, rather than liberal majoritarian democracy, it can be argued in return that any system that puts human rights on the back foot is ultimately doomed to fail.

At the heart of these debates lies a moral dilemma - namely the need to make a value judgement. In countries such as Bosnia and Herzegovina, which

39 For a wider discussion on this topic see Stefan Graziadei, "Democracy v Human Rights? The Strasbourg Court and the Challenge of Power Sharing," European Constitutional Law Review 12, no. 1 (May 2016): 54-84, https://doi.org/10.1017/S15740196160ooo43.

40 For a discussion on identity and peace-building within power-sharing systems see Brendan O'Leary, "Power Sharing in Deeply Divided Places: An Advocate's Introduction," in Power Sharing in Deeply Divided Places, eds. Joanne McEvoy and Brendan O'Leary (Philadephia: University of Pennsylvania Press, 2013), 1-66.

41 Specifically for Bosnia on this issue see Valery Perry, "More Ethnic Politics and Virtual Partition will not Help," Bosnia Daily, 3o May 2016, 9-10, http://www.democratizationpolicy.org/pdf/BDaily_Perry\%2oUS\%2oCongress\%2ohearing_5-30-16.pdf. 
have experienced extensive violence, and in which ethnic relations are characterised by antagonism and mistrust, can the focus on preserving peace through stable power-sharing institutions be considered more important than the focus on fundamental freedoms and human rights of each and all individuals? The ECHR judgement clearly answered this question by arguing against this focus on stability and pushing forward the importance of human rights in post-conflict societies. The inability of Bosnian elites to implement this judgement demonstrates that this debate might have been decided by the ECHR, but Bosnian elites are reluctant to give up their monopoly of power, and they are unwilling to create a shared vision for the future of the state, in which those citizens that do not self-recognise as Bosniaks, Serbs or Croats would also be included, recognised and have equal access to the state and its institutions.

\subsection{The Federalisation Process - Countering or Embracing Ethnic Division?}

Bosnia's federalisation since 1995 has been characterised by a slow, externally driven centralisation process, the undermining of ethnic-exclusivity of the entities (and cantons) through the Constituent Peoples Case judgement of the Bosnian Constitutional Court, and by countering forces, principally the elites from the three constituent peoples, who have pushed the interpretation of Bosnia's federal system ever-closer towards the idea of an ethnic federal system. Demands by Bosnian Croat elites for a third - Croat - entity in Bosnia clearly fit this pattern. ${ }^{42}$ The language of the political elites of the three constituent peoples has been one characterised by exclusivity and at times bordering on hate speech. ${ }^{43}$ Ethnic relations, in other words, remain full of tensions more than twenty years after the end of hostilities. The conflict, as some have argued, has become frozen, and is now continued through the means of politics, in which each side attempts to push for their own benefits and their own vision of Bosnia, which resultantly creates a situation of permanent paralysis in the institutions and stasis in terms of political progress. ${ }^{44}$

42 Florian Bieber, "Croats in Bosnia and Herzegovina," in Bosnia-Herzegovina since Dayton: Civic and Uncivic Values, eds. Ola Listhaug and Sabrina Ramet (Bologna: Longo Editore Ravenna, 2013), 309-328.

43 As an example see Gerard Toal, "'Republika Srpska Will have a Referendum': The Rhetorical Politics of Milorad Dodik," Ethnopolitics 41, no. 1 (2013): 166-204.

44 Valery Perry, "The Elephant in the Room - Bosnia and Herzegovina's unmentionable Constitutional Disability," Transconflict (July 2014), http://www.transconflict.com/2014/ o7/elephant-room-bosnia-herzegovinas-unmentionable-constitutional-disability-o97/. 
What this means for federalism in Bosnia is that the very idea of federalism remains contested in the country. Federalism has different meanings, not only for different academics as demonstrated in the introduction, but also for the peoples in Bosnia. This is not per se surprising, as multinational federations are characterised by competing versions of what the state is and why it is federal (and what the nature of federalism is). ${ }^{45}$ This can also be found in well-established Western multinational and bi-national federations such as Canada and Belgium, where federalism as an idea is contested and where the federal institutional architecture serves different purposes for the different groups in the country. ${ }^{46}$ Yet, where Bosnia is different to these countries is that the very nature of federalism itself is contested, as a result of the contestation of the whole state. Serb and Croat elites continue to flirt with ideas of separation and secessionism, while Bosniak elites despise the idea of federalism as they see it as a form of ethnic division of the country. In other words, rather than just having different interpretations of what federalism is and why it was chosen as an organisational principle for the country, elites in Bosnia dispute the very nature of Bosnia as a federal country. ${ }^{47}$ William Riker teaches us that the creation of a federal system is always based on a compromise between elites representing the centre and those representing the units within the future federal system. ${ }^{48}$ In Bosnia, representatives of the international community need to be added to this equation ${ }^{49}$ - as they played a key role in the DPA and have been a major driving force for the federal system, which explains why it remains so contested to this day by local elites. Despite the Constituent Peoples judgement of the Bosnian Constitutional Court and the Sejdić-Finci judgement of the ECHR, not much has changed in the wider dynamics of Bosnian federalism - it remains very much a zero-sum game between the elites of the three recognised constituent peoples, at the expense of any political progress.

45 Michael Burgess, "Multinational Federalism in Multinational Federation," in Multinational Federalism - Problems and Prospects, eds. Michel Seymour and Alain-G. Gagnon (Basingstoke, New York: Palgrave MacMillian, 2012), 23-44.

46 Raffaele Iacovino and Jan Erk, "The Constitutional Foundations of Multination Federalism: Canada and Belgium," in Multinational Federalism - Problems and Prospects, eds. Michel Seymour and Alain-G. Gagnon (Basingstoke, New York: Palgrave MacMillian, 2012), 205-230.

47 For a more detailed discussion on this see Keil, Multinational Federalism, 125-176.

48 William Riker, Federalism: Origins, Operation, Significance (Boston: Little Brown, 1964).

49 Bermeo refers to federal systems which have been installed through international intervention as imposed federalism. See Nancy Bermeo, "The Import of Institutions," Journal of Democracy 13, no. 2 (April 2002): 96-110. 
This raises a number of fundamental questions about the use of federalism in post-conflict societies. As discussed above in the case of power-sharing, one must ask whether giving territorial autonomy to elites representing groups that have used violence to promote their case will in the long-term be rewarding, especially if this autonomy comes at the expense of the rights of other groups in these territorial units. ${ }^{50}$ There is now an established body of literature discussing the 'paradox of federalism', namely the fact that while federalism might be able to overcome demands for secession, it also provides institutional mechanisms which enhance minorities' abilities to declare independence at a later stage. ${ }^{51}$ Yet, while we know about some of the challenges linked to the implementation of a federal political system as a tool to overcome ethnic tensions, overall we still know very little about the uses and dangers of federalism as a tool for conflict resolution in ethnically divided, war-torn societies. Having said this, there are some lessons that can be learnt from Bosnia in this regard. For example, while the complex federal system might have been a necessity in 1995 in order to end the war and bring the warring groups to the negotiation table, the rigidity of the Dayton Constitution has made any changes in the post-war period impossible. What is more, in a contested system such as Bosnia, where ideas of ethnic federalism rival those of territorial conceptions of autonomy, ethnic federalism will prevail if the system is dominated by ethnic elites who see the whole political game as a continuation of the conflict over territory and group dominance. Finally, an important lesson to learn from the federal experience in Bosnia is that these post-war institutional arrangements do not organically change and reform themselves over time. While Bosnia's territorial and institutional arrangements reflect the necessity for cooperation, compromise and ethnically homogenous territories that were a precondition for the successful conclusion of the Dayton Peace Conference, today it can clearly be argued that the same arrangements have become a symbol for the permanent crisis of the political system and its lack of progress, liberalisation and democratisation. ${ }^{52}$ Having said this, what has become obvious in the previous discussion is that it has become relatively easy to identify the ills in Bosnia's system, but the question of how to correct them and how to prevent similar

50 This issue is discussed in more detail in Paul Anderson and Soeren Keil, "Federalism: A Tool for Conflict Resolution?," 5o Shades of Federalism (2017), http://5oshadesoffederalism.com/federalism-conflict/federalism-tool-conflict-resolution/.

51 See for exampleJan Erk and Lawrence Anderson, eds., The Paradox of Federalism-Does SelfRule Accommodate or Exacerbate Ethnic Divisions? (Abingdon, New York: Routledge, 2010).

52 Vedran Dzihic, "Bosnien und Herzegowina in der Sackgasse? Struktur und Dynamik der Krise fünfzehn Jahre nach Dayton," Südosteuropa 59, no. 1 (2011): 50-76. 
mistakes in other post-war countries remains largely unanswered and much more research is needed on this issue.

\subsection{What about Equality?}

In the debates about the future of federalism and power-sharing in Bosnia, the question of equality remains of fundamental importance. Elites of the three constituent peoples feel that their ethnic groups are disadvantaged and discriminated by the DPA and the current institutional provisions. They therefore argue that reforms are necessary in order to address their perceived (more so than real) discrimination and unequal treatment. Likewise, the Sejdić-Finci judgement highlighted that beyond the three main ethnic groups that are identified as constituent peoples, there are other people(s) in Bosnia, who are constitutionally excluded from certain institutions, and who have become marginalised in the wider political discourse. In other words, the multinational state that is Bosnia and Herzegovina is a good example of the multifarious dimensions involved in questions about equality. Discussions in Bosnia highlight the importance of equality between different ethnic groups, particularly those that have previously been involved in fighting over inclusion and exclusion in the state. But the political debate in Bosnia also demonstrates the need for a consideration of equality beyond these ethnic groups, and the elites that represent them. The focus on the main groups might alienate other smaller groups. It might also discriminate against those citizens that refuse to identify with any group; in Bosnia there are no institutional protections and guarantees for those considering themselves as 'Bosnian' for example. Squaring the circle between these different understandings of equality, as well as the wider philosophical and theoretical implications, has been discussed in the academic literature, ${ }^{53}$ but its application in post-war states remains highly controversial and indeed very difficult. While federalism, as used in $\mathrm{BiH}$ to accommodate different groups and end a violent conflict, can make a contribution to ensuring peace and bringing in a certain degree of democracy and equality, there is no guarantee that it will fundamentally overcome ethnic rivalries and ongoing tensions, including feelings of discrimination. In Bosnia, however, this discrimination is not only one of perception; as demonstrated in the case of Sejdić-Finci, it

53 Ferran Requejo, "Three Theories of Liberalism for the Three Theories of Federalism: A Hegelian Turn," in Multinational Federalism-Problems and Prospects, eds. Michel Seymour and Alain-G. Gagnon (Basingstoke, New York: Palgrave MacMillian, 2012), 45-68. See also Ferran Requejo, "National Pluralism, Recognition, Federalism and Secession (or Hegel Was a Clever Guy)," in Understanding Federalism and Federation, eds. Alain-G. Gagnon, Soeren Keil and Sean Mueller (Farnham, New York: Ashgate, 2015), 157-176. 
is certainly very real with real political consequences for the affected groups. Therefore, finding a balance between giving rights and autonomy to territorially organised groups (through federalism), while at the same time preventing discrimination against other groups remains a key challenge for any federal system. ${ }^{54}$ Innovative institutional mechanisms need to be employed to ensure that the inclusion of certain groups through power-sharing and territorial autonomy does not result in the exclusion of certain other groups. One of the key reasons why the implementation of the ECHR judgement in Sejdić-Finci has been lacking until today is the fact that its implementation allows the elites of the three constituent peoples to focus on their perceived discrimination and consequently demand wider reforms to improve their situation in the political system. In other words, implementation of the ECHR judgement would not only threaten the whole basis of the Dayton Agreement as a peace-building mechanism, but it would also open up the question of minority inclusion in Bosnia and undo all institutional arrangements, without any compromises and agreements in sight on future provisions amongst the ruling elites. Sejdić-Finci implementation is complex, because Bosnia's system is complex, and Bosnia's system is complex because it attempts to bridge two contradictory principles the protection of group rights and power-sharing amongst ethnic elites on the one side, and the protection of human rights and fundamental freedoms for all Bosnian citizens on the other.

\section{5}

\section{Conclusion}

Bosnia and Herzegovina remains one of the most complicated political systems in the world. It combines a multidimensional federal system with powersharing amongst the elites from the three constituent peoples. Yet, as the discussion above demonstrates, it also remains a political system that is deeply contested by its leading political agents. The institutional framework deployed at Dayton served multiple purposes, first and foremost to end the war that engulfed the country from 1992 to 1995. But it also laid the foundation for elite cooperation and federalisation, in order to provide a political and institutional compass for the post-conflict era, thereby contributing to both democratisation and state-building.

54 On this issue see Ronald Watts, "Can Federal Political Systems Accommodate National Minorities?," in States Falling Apart? Secessionist and Autonomy Movements in Europe, eds. Eva Maria Belser et al. (Bern: Stämpfi Verlag, 2015), 37-46. 
When looking at the question of equality in multinational states, the Bosnian experience teaches us a number of important lessons. It comes as no surprise that equality, like democracy and federalism, is a contested concept in multinational states, and that the different groups and their representatives are very aware of the dangers of exclusion and discrimination. This is particularly important in a post-conflict context, such as Bosnia, in which ethnic relations remain strained and distrust remains. Another important lesson to learn from Bosnia is that the inclusion of some groups (in Bosnia's case the three constituent peoples) might lead to the exclusion of other groups, and thereby institutions designed to ensure equality and inclusion can become exclusive and discriminatory. The discussion on the Sejdić-Finci judgement of the ECHR has highlighted this point in detail. Thinking about institutional design in post-war societies therefore requires a degree of innovation and flexibility that allows the protection of major groups, particularly those that were involved in the fighting, while at the same time preventing the exclusion of other, often smaller, groups. Mechanisms for this exist, such as North Macedonia's reference to 'majority' and 'non-majority' communities rather than referring to fixed ethnic groups. A final lesson to learn from Bosnia is that post-conflict states need time to adapt, but also flexibility to change over time. Bosnia has changed substantially since 1995, but this change has mainly been driven externally, and has not resulted in a fundamental revision of Bosnia's Constitution. The constitutional provisions that served as a tool of peace-building in 1995 have proven to be a straightjacket when one looks at democratisation and state-building. In order to address this in other post-conflict situations, constitutional mechanisms need to be precise and protect certain rights, but constitutional provisions must also be allowed to change and evolve over time.

In summary it can be said that Bosnia offers a fascinating case-study in terms of equality (and inequality) in a multinational, post-conflict country. Countries discussing federalism as a tool of conflict resolution, such as Ukraine, Syria and Myanmar, can learn from the Bosnian experience, both in terms of what worked and what did not work.

\section{Bibliography}

Anderson, Paul and Soeren Keil. "Federalism: A Tool for Conflict Resolution?" 5o Shades of Federalism (2017). http://5oshadesoffederalism.com/federalism-conflict/ federalism-tool-conflict-resolution/.

Bahtić-Kunrath, Birgit. "Of Veto Players and Entity Voting: Institutional Gridlock in the Bosnian Reform Process." Nationalities Papers 39, no. 6 (2011): 899-923. https://doi. org/10.1080/oogo5992.2011.614224. 
Bassuener, Kurt. "The Dayton Legacy and the Future of Bosnia and the Western Balkans - House Foreign Affairs Committee Hearing." Written Statement for the Congressional Record (April 2018). http://www.democratizationpolicy.org/pdf/ Bassuener_US_Congressional_Hearing_Written_Statement_4_18.pdf.

Bermeo, Nancy. "The Import of Institutions.” Journal of Democracy 13, no. 2 (April 2002): 96-110.

Bieber, Florian. "Croats in Bosnia and Herzegovina." In Bosnia-Herzegovina since Dayton: Civic and Uncivic Values, edited by Ola Listhaug and Sabrina Ramet, 309328. Bologna: Longo Editore Ravenna, 2013.

Bieber, Florian. Post-War Bosnia, Ethnicity, Inequality and Public Sector Governance. Basingstoke, Hampshire: Palgrave Macmillan, 2006.

Burg, Steven and Paul Shoup. The War in Bosnia-Herzegovina: Ethnic Conflict and International Intervention. Armonk, London: M.E. Sharpe, 1999.

Burgess, Michael. "Multinational Federalism in Multinational Federation." In Multinational Federalism - Problems and Prospects, edited by Michel Seymour and Alain-G. Gagnon, 23-44. Basingstoke, New York: Palgrave MacMillian, 2012.

Burgess, Michael. Comparative Federalism: Theory and Practice. Basingstoke, New York: Routledge, 2006.

Daalder, Ivo. Getting to Dayton - The Making of America's Bosnia Policy. Washington D.C.: Brookings Institute, 2000.

Dzihic, Vedran. "Bosnien und Herzegowina in der Sackgasse? Struktur und Dynamik der Krise fünfzehn Jahre nach Dayton." Südosteuropa 59, no. 1 (2011): 50-76.

Erk, Jan and Lawrence Anderson, eds. The Paradox of Federalism - Does Self-Rule Accommodate or Exacerbate Ethnic Divisions?. Abingdon, New York: Routledge, 2010.

Graziadei, Stefan. "Democracy v Human Rights? The Strasbourg Court and the Challenge of Power Sharing." European Constitutional Law Review 12, no. 1 (May 2016): 54-84. https://doi.org/10.1017/S15740196160ooo43.

Hoare, Attila. "The Croatian Project to Partition Bosnia-Hercegovina, 1990-1994." East European Quarterly 31, no. 1 (March 1997): 121-138.

Holbrooke, Richard. To End a War. New York: The Modern Library, 1999.

Iacovino, Raffaele and Jan Erk. "The Constitutional Foundations of Multination Federalism: Canada and Belgium." In Multinational Federalism - Problems and Prospects, edited by Michel Seymour and Alain-G. Gagnon, 205-230. Basingstoke, New York: Palgrave MacMillian, 2012.

International Crisis Group. “Implementing Equality:The ‘Constituent Peoples’ Decision in Bosnia and Herzegovina." ICG Balkans Report, no. 128. Sarajevo, Brussels: 2002.

Kasapović, Mirjana. "Bosnia and Herzegovina: Consociational or Liberal Democracy?." Politička misao 42, no. 5 (2005): 3-3o.

Keil, Soeren and Anastasiia Kudlenko. "Bosnia and Herzegovina 20 Years after Dayton: Complexity Born of Paradoxes." International Peacekeeping 22, no. 5 (2015): 471-489. 
Keil, Soeren and Valery Perry. "Introduction: Bosnia and Herzegovina 20 Years after Dayton." International Peacekeeping 22, no. 5 (2015): 463-470.

Keil, Soeren and Valery Perry. "Introduction: State-Building and Democratization in Bosnia and Herzegovina." In State-Building and Democratization in Bosnia and Herzegovina, edited by Soeren Keil and Valery Perry, 1-14. London, New York: Routledge, 2015 .

Keil, Soeren. "Mythos und Realität eines ethnischen Föderalismus in Bosnien und Herzegowina." Südosteuropa Mitteilungen 50, no. 1 (2010): 76-86.

Keil,Soeren.MultinationalFederalisminBosniaandHerzegovina.Farnham:Ashgate, 2013. Lijphart, Arend. Democracy in Plural Societies. New Haven: Yale University Press, 1977. McCrudden, Christopher and Brendan O'Leary. Courts and Consociations. Oxford, New York: Oxford University Press, 2013.

Mujanović, Jasmin. Hunger and Fury - The Crisis of Democracy in the Balkans. London: Hurst and Co., 2018.

Neussl, Peter. "The Constituent Peoples Decision of the Constitutional Court and the Sarajevo-Mrakovica Agreement- A 'Milestone Product' of the Dayton Concept?." In Dayton and Beyond: Perspectives on the Future of Bosnia and Herzegovina, edited by Christophe Solioz and Tobias Vogel, 65-73. Baden-Baden: Nomos, 2004.

O'Leary, Brendan. "Power Sharing in Deeply Divided Places: An Advocate's Introduction." In Power Sharing in Deeply Divided Places, edited by Joanne McEvoy and Brendan O'Leary, 1-66. Philadephia: University of Pennsylvania Press, 2013.

Office of the High Representative in Bosnia and Herzegovina. "Federation of Bosnia and Herzegovina, Map." Published on October 7, 2003. http://reliefweb.int/map/ bosnia-and-herzegovina/federation-bosnia-and-herzegovina.

Perry, Valery. "Constitutional Reform in Bosnia and Herzegovina: Does the Road to Confederation go through the EU?." International Peacekeeping 22, no. 5 (2015): 490-510.

Perry, Valery. "Constitutional Reform Processes in Bosnia and Herzegovina: TopDown Failure, Bottom-Up Potential, Continued Stalemate." In State-Building and Democratization in Bosnia and Herzegovina, edited by Soeren Keil and Valery Perry, 15-40. London, New York: Routledge, 2015.

Perry, Valery. "More Ethnic Politics and Virtual Partition will not Help." Bosnia Daily, May 30, 2016. http://www.democratizationpolicy.org/pdf/BDaily_Perry\%2oUS\%2O Congress\%2ohearing_5-30-16.pdf.

Perry, Valery. "The Elephant in the Room - Bosnia and Herzegovina's unmentionable Constitutional Disability." Transconflict (July 2014). http://www.transconflict. com/2014/o7/elephant-room-bosnia-herzegovinas-unmentionable-constitutionaldisability-097/.

Requejo, Ferran. "National Pluralism, Recognition, Federalism and Secession (or Hegel Was a Clever Guy)." In Understanding Federalism and Federation, edited by Alain-G. Gagnon, Soeren Keil and Sean Mueller, 157-176. Farnham, New York: Ashgate, 2015. 
Requejo, Ferran. "Three Theories of Liberalism for the Three Theories of Federalism: A Hegelian Turn." In Multinational Federalism - Problems and Prospects, edited by Michel Seymour and Alain-G. Gagnon, 45-68. Basingstoke, New York: Palgrave MacMillian, 2012.

Riker, William. Federalism: Origins, Operation, Significance. Boston: Little Brown, 1964. Silber, Laura and Alan Little. The Death of Yugoslavia. London: Penguin Books and B BC Books, 1996.

Toal, Gerard. “'Republika Srpska Will have a Referendum': The Rhetorical Politics of Milorad Dodik." Ethnopolitics 41, no. 1 (2013):166-204.

Toe, Rodolfo. "Census Reveals Bosnia's Changed Demography." BalkanInsight, June 3o, 2016. http://www.balkaninsight.com/en/article/new-demographic-picture -of-bosnia-finally-revealed-o6-3o-2016.

Turton, David, ed. Ethnic Federalism: The Ethiopian Experience in Comparative Perspective. Martlesham, Rochester: James Currey, 2006.

Wakelin, Elyse. “The Sejdic and Finci Case: More Than Just a Human Rights Issue?." E-International Relations (October 2012). http://www.e-ir.info/2012/10/31/thesejdic-and-finci-case-more-than-just-a-human-rights-issue-for-bosnia-and-herzegovina/.

Wakely, Lindsey. "From Constituent Peoples to Constituents: Europe Solidifies Fundamental Political Rights for Minority Groups in Sejdic v. Bosnia." North Carolina Journal of International Law and Commercial Regulation 36, no. 1 (Autumn 2010): 233-254.

Watts, Ronald. “Can Federal Political Systems Accommodate National Minorities?." In States Falling Apart? Secessionist and Autonomy Movements in Europe, edited by Eva Maria Belser, Alexandra Fang-Bär, Nina Massüger and Rekha Oleschak Pillai, 37-46. Bern: Stämpfi Verlag, 2015.

Woelk, Jens. "Bosnia and Herzegovina: Trying to Build a Federal State on Paradoxes." In Constitutional Dynamics in Federal States - Sub-national Perspectives, edited by Michael Burgess and Alan Tarr, 109-139. Kingston, Montreal: McGill-Queen's University Press, 2012.

Zdeb, Aleksandra. "A Federation like No Other: The Case of Bosnia and Herzegovina." 5o Shades of Federalism (2018). https://5oshadesoffederalism.com/case-studies/federation-like-no-case-bosnia-herzegovina/. 